\title{
Visions of a Colony: History on (dis)play at the Museum of Sydney
}

\author{
ARMANDA SCORRANO
}

$\mathrm{H}$

istory museums have long been one of the most popular and trusted avenues through which members of the public gain an understanding of the past. From their inception, public museums have been prime disseminators of knowledge, and while other functions have been added to their repertoire, this continues to play a major role. In Australia, progressive museums have in recent decades taken on new ways of representing the past. But while disrupting traditional historical narratives, wholesale adoption of academic fashions has in some instances undermined the museum's ability to communicate history to the public. When it first opened in 1995, the Museum of Sydney (MoS) received praise from some quarters for its innovative representations of the city's history, but it was increasingly criticised for its inaccessibility due to its postmodern approach. This highlights the tension between curatorial style and content that museums must negotiate in order to meet the needs of their audiences. Taking MoS as a 
case study, this article argues that public history museums are limited in their ability to break new ground when they must also remain accessible and relevant to the publics they serve.

In the Australian context, as Hamilton and Ashton have demonstrated, museums are one of the most trustworthy historical sources due to their institutional authority and their use of objects in representing the past. ${ }^{1}$ As an institution with a mandate for research and education, the museum has had the authority to present the truth as though it were a one-dimensional, static, unquestionable reality. Indeed, museums became places where 'politically organized and socially institutionalized power' appeared natural and legitimate, ${ }^{2}$ rendering visitors often unaware of the lenses through which ideas about the past were being communicated. ${ }^{3}$ The museum thus became a powerful tool of inculcation.

The emergence of social history in the 1970s impacted museological practice in a profound way. Knowledge - its pursuit, realization and deployment - came to be seen as inherently political, ${ }^{4}$ and the ways in which differences and inequalities of ethnicity, gender, sexuality and class were reproduced in the academy came under scrutiny. Consequently, there were calls for greater attention to the processes by which knowledge was produced and disseminated, privileged and marginalized. Many museums heeded the call, and before long began to include women, workers, Indigenous people, migrants and others who had previously been excluded from historical narratives.

A significant component of this 'new museology' ${ }^{5}$ - and the historiographical changes that were in part driving it - was a recognition of the multiplicity of historical interpretations. Museums were soon promoting themselves as 'forums for debate' and 'meeting places of ideas' rather than 'authorities'. ${ }^{6}$ This is precisely how $\mathrm{MoS}^{7}$ and the National Museum of Australia ${ }^{8}$ articulated their role, along with overseas institutions such as the Museum of London. ${ }^{9}$ Yet the question remains whether it is even possible for museums to effectively communicate divergent historical narratives. Perhaps, as Dean and Rider suggest, public museums are simply not the right place to pursue such 'highly nuanced ideas or complex concepts' ${ }^{10}$ This article examines how MoS, in its early days, balanced engagement with historiographical developments on the one hand, with meeting the needs of its various audiences on the other. 


\section{ESTABLISHMENT OF MOS}

As its full title indicates, the Museum of Sydney is located on the site of the first Government House. Although the exhibitions within the Museum extend far beyond the site's interpretation, it is the site and what it means to people that underpinned the Museum's early work. First Government House (FGH), built in May 1788, was the first permanent building constructed in the new colony of New South Wales. ${ }^{11}$ Until its demolition in 1846, it was the embodiment of colonial power in Sydney. The site was largely forgotten until an archaeological survey in 1982 uncovered the footings of the original house, as well as extensive deposits of pottery, glass, bone and metal fragments. ${ }^{12}$ This generated immediate interest amongst archaeologists, historians and the general public, and the NSW Government was called on to protect the find. ${ }^{13}$ The fierce public pressure to extend the archaeological dig and preserve the site can in part be accounted for by the renewed interest in Australian history generally, and of Sydney history in particular. This sudden fascination with Australia's past paralleled the resurgence of Australian nationalism from the late 1960s, spurred on by the celebrations in 1970 commemorating the bicentenary of Captain Cook's 'discovery' of Australia, and the lead up to the 1988 bicentenary of European 'settlement'. ${ }^{14}$ Groups such as the Sydney History Group, formed in 1977, fostered scholarship and interest in the city's past, and cultivated a desire to preserve historic urban sites such as FGH. ${ }^{15}$

Agreeing to protect the site, the Government proposed a museum be built to commemorate it. Various government institutions were approached to run the museum, including the Historic Houses Trust (the Trust). When asked for their opinion on the proposed museum, the Trust advised the Government not to build one at all, saying it wasn't necessary, sustainable or viable. ${ }^{16}$ Yet the Trust was appointed manager of the new museum in September $1988 .{ }^{17}$ Construction began in August 1990 and the Museum opened five years later. ${ }^{18}$

The then Director of the Trust, Peter Watts, explained that the Trust's philosophy of always trying to understand the significance of the place they're working with underpinned their approach to the FGH site and subsequently to MoS. ${ }^{19}$ The Trust, after much internal debate, agreed that the most significant aspect of the site was its symbolism. Indeed the remains of the original site were too fragile to be permanently exposed, necessitating their continued preservation underneath Bridge Street and the plaza pavings. This meant that the Museum didn't actually have a collection to display, which was one of the reasons the Trust had been 
opposed to a museum on the site in the first place. However, the lack of a collection also presented a unique opportunity: the Trust could now create a Museum about ideas and symbolism without the constraints of having to interpret a physical structure or a tangible collection. Watts has noted that the real significance of the site - in terms of its future as a museum - 'was what it stood for, and it stood for the arrival of the British in Australia... It was about a tuning point in Australian history, but that turning point was of great symbolic significance'.$^{20}$ Thus, rather than the site's physical components determining its importance, its significance lay instead in what the site represented and what it meant to different groups.

Despite the enormous amount of painstaking work that went into creating MoS, Watts has suggested that what the public saw in 1995 was always envisaged as only a first attempt. He explained that,

All you can do in the mad rush to get a museum open is a first putt at it. Then, as the ideas develop, as the collections develop, and so on, then you start to enrich and enhance, and layer in extra things. This is what has happened at [MoS]. So apart from just responding to criticism, it was actually learning... I think a lot of criticism in the early days of institutions is unreasonable and unfair because it takes a while to work them out. ${ }^{21}$

Indeed, Watts had intentionally reserved $\$ 1$ million from the original development budget because he knew that what they were doing was risky and he wanted accessible money to change the approach if necessary. ${ }^{22}$ So what was it that MoS was trying to do, and did it work?

\section{EMMETT'S HISTORIOGRAPHICAL VISION}

In terms of its historiographical approach, to a large extent MoS was simply following in the footsteps of several of its contemporaries. The introduction of social history in museums had been a catalyst for usurping the single-narrative approach favoured previously. As social history took individual communities, places and people as the foci of study and as subjects for display, the fallacy of a single public - with a single history - began to emerge. The museum could no longer occupy the role of a public space imagining and representing a rigid, linear and singular narrative of the past. ${ }^{23}$ Like Hyde Park Barracks Museum before it, MoS set out to undermine 'the dominant consensual models of Australian history'. ${ }^{24}$ 
The philosophical foundations of MoS' approach were largely the work of its first Senior Curator, Peter Emmett, who was at MoS from 1992 until 1999. Emmett was responsible for overseeing the early development of the Museum and was the driving force behind the direction the Museum took, assembling a team of artists, technicians, musicians, historians and creative thinkers that crafted the Museum's exhibitions. Watts has described Emmett as 'brilliant' but also 'very strong willed and strong minded', the latter being that which ultimately resulted in the cessation of his involvement with MoS. ${ }^{25}$ Emmett's approach was controversial, eliciting both derision and praise. ${ }^{26}$ Ann Curthoys described it as 'revisionist, post-colonial, post-modern, conceptual and interdisciplinary'. ${ }^{27}$

The three main themes underpinning MoS were pluralistic historical interpretation, postcolonialism and spatial history. ${ }^{28}$ The notion of multiple historical narratives arose out of postmodernism. In his seminal work - the Postmodern Condition: A Report on Knowledge - French philosopher Jean-François Lyotard defined postmodernism as 'incredulity toward metanarratives'. ${ }^{29}$ Lyotard invented the term 'metanarrative' or 'grand narrative' to attack the belief in historical progress by highlighting the multiplicity of historical interpretations that were available. ${ }^{30}$ The avoidance of metanarratives was perhaps the most striking element of MoS when it first opened. As Emmett commented, the Museum's 'profusion of visual and material culture aims to subvert the common assumption that this period in our history was very simple', noting that it was instead 'dense and exciting'. ${ }^{31}$ Suggesting there was a single - white, European, middle-class - history of Sydney was a limiting position to hold. The reality of multiple, and at times competing, narratives demonstrates the existence of a richer history to the one commonly understood. MoS was keen to facilitate this. As curator Sue Hunt summarised,

this is not going to be a stuffy and boring museum, it's going to be a museum of interpretation ... we're saying there isn't one truth in history'. ${ }^{32}$

Emmett argued that there could be no meaningful talk about the FGH site because it meant different things to different people. ${ }^{33}$ The site was contested ground in 1788 and continued to be contested ground over 200 years later. Yet the absence of a consensus as to the site's meaning should not have precluded meaningful discussion about it. Multiple meanings are still each meaningful. However, clarity appeared to be an anathema to Emmett. An example of this is his description of a museum 
as 'a spatial composition, a sensory and sensual experience; a place to enter, senses and body alive. Its meanings are revealed through the physical experience of moving through $\mathrm{it}^{\prime} .{ }^{34} \mathrm{He}$ continues, explaining MoS' medium and methodology as being 'about the poetics of space, the choreography of people, the relation of things and senses, spatial and sensory compositions, to exploit the sensuality and materiality of the museum medium'. His descriptions ventured even further into the obscure when he suggested there was a connection between the words 'museum', 'mushroom' and 'murphy' (an Irish name for a potato) based on their proximity to each other in the Oxford English Dictionary. ${ }^{35}$ Emmett's vision for MoS seemed to be more about creating a sensorial, rather than a knowledge-sharing, experience. He suggested the fundamental role of a museum was to be a cultural space for exploration and reflection, where meanings could be renegotiated. ${ }^{36}$ In this way, rather than presenting the history of Sydney, MoS was envisaged as a display house for a range of histories loosely clustered around the 'theme' of Sydney. ${ }^{37}$

Intertwined with pluralistic historical interpretation, postcolonialism significantly influenced Emmett's approach at MoS. He wanted the Museum to 'embrace the historical revisions demanded of a postcolonial collage'. Thus the FGH site was framed as a 'contested' place and as a symbolic 'turning point' in the history of the continent's inhabitants. At MoS there was to be a privileging of Indigenous experiences post-1788 alongside a refusal to celebrate the invasion and its consequences. By 1996 the Museum was describing itself as 'a multimedia, multi-disciplinary installation about the nature and narration of this place they called Sydney. MoS seeks not to enclose colonial histories but to liberate a post-colonial space for other voices to speak, past and present ${ }^{\prime} .^{38}$ Emmett's museological approach fell squarely under the purview of 'new museology', which was itself influenced by postmodernism and post-colonial theory. ${ }^{39} \mathrm{He}$ was soon lauded as 'Australia's first postmodern curator'. ${ }^{40}$

Spatial history was the third key influence on Emmett's plan for MoS. The term - coined by Paul Carter in his 1987 book The Road to Botany Bay: A Spatial History ${ }^{41}$ - was frequently used in early documents to describe the Museum's framework. Spatial history was seen by MoS as an alternative to 'tired chronology wedded to imperial versions of the past'. ${ }^{42}$ Emmett explained that spatial history sees place as 'culturally determined: the journeys of people/cultures moving through its space groove the landscape, create borderlands and meet/converge, become entangled' ${ }^{43}$ He describes it as refraining from ordering its subject matter 'into a nationalist enterprise, a cause-and-effect pageant of firsts 
and greats that artificially completes the imperial plan'. Rather, it 'proceeds metaphorically and suggests the plurality of directions across place and time by the dialogue of many criss-crossing voices, past and present' ${ }^{44}$ Curiously, what Emmett appears to be describing could as easily be characterised as part of the well-established field of social history.

Emmett has explained that, in summary, what MoS boils down to is an examination of the nature of authority and power. This in fact extended beyond the history of Sydney to include an examination of museological practice. As Emmett opined, what 'is potentially radical about this museum [is that] it brings a self-critical approach to museology, selective traditions and academic disciplines, which become obsessed with how to classify their collections rather than looking at these things as a reflection of human use'. ${ }^{45}$ Emmett was thus concerned with the role the museum had previously played in society:

The museum is a colonial inheritance. It has defined so much of what is important by virtue of collecting it and celebrating it and we are opening things up for discussion - questioning a lot of the premises of what is important about the past. ${ }^{46}$

This was an admirable pursuit on the part of Emmett and his team. But were they able to provoke visitors into critically examining what the Museum did? Or were the displays at MoS too esoteric to elicit anything more than confusion?

\section{ART INSTALLATIONS AND HISTORICAL DISPLAYS}

Emmett's entire philosophy at MoS was on show before visitors had even set foot inside the building, neatly encapsulated in the sculptural installation Edge of the Trees. Created by artists Janet Laurence and Fiona Foley, Edge of the Trees symbolises the encounter of two cultures, which is reinforced by the collaboration of the two artists - Foley an Indigenous Australian and Laurence a non-Indigenous Australian. Laurence and Foley were chosen by a selection committee to develop this heavily curated piece envisaged by Emmett. ${ }^{47}$ Emmett had already prepared a concept brief that defined the role and message he wanted the sculpture to encompass and this was distributed amongst a group of artists that he had invited to compete for the commission. The idea for the installation came from a quote by historian Rhys Jones that Emmet had found inspirational: 
the discoverers struggling through the surf were met on the beaches by other people looking at them from the edges of the trees. Thus the same landscape perceived by the newcomers as alien, hostile or having no coherent form, was to the Indigenous people their home, a familiar place, the inspiration of dreams. ${ }^{48}$

Jones' phrase 'the edge of the trees' resonated with Emmett, and the art installation became the 'dominant metaphor of place' for MoS and the FGH site. Emmett explained the sculpture as an 'invitation to enter this museum meeting place as a shared and contested site of environmental and cultural memory'. ${ }^{49}$ He positions it as 'an extended metaphor on contact, memory, the edge of nature-culture'.$^{50}$ So while FGH is a symbol of colonial authority, the 'bigger issue is about contact between two cultures, two world views'. ${ }^{51}$ Thus Emmett's concept brief required the artists 'to respond directly to the culturally charged symbolism inherent within the site'. ${ }^{52}$

The sculpture comprises twenty-nine poles, representing twentynine Indigenous clans in and around Sydney, encasing various materials from Indigenous history and culture, including honey, resin, oxides, shells, bones and hair. ${ }^{53}$ The installation includes sound recordings of Indigenous people speaking the names of Indigenous groups in the Sydney area (sourced from an eighteenth-century fishing map). ${ }^{54}$ The signatures of members of the First Fleet are engraved onto zinc plates, which are recessed into some of the wooden poles. Others have the botanical names of local plant species that grew in the original first Government House garden burnt into them. The names of Indigenous men and women who lived in the region, along with notes from Lieutenant William Dawes' eighteenth-century notebooks detailing the Indigenous names for local places, are carved onto pillars. ${ }^{55}$ The sculpture is intended as an approachable piece, with visitors invited to walk amongst the poles, touch the engravings, and put their ears to the sound pillars to hear the whispering voice recordings. In this way they may gain some appreciation for how Europeans and Indigenous people each experienced the first contact - the former approaching unfamiliar bushland and people while the latter peered out at the invaders from the 'edge of the trees'.

Emmett explained that above all, 'Edge of the Trees is about the poetic evocation of the sense of place for Sydney today, through engagement with the poetics of space, a material sensuality, and the alchemical qualities of flux and transformation' ${ }^{56}$ This is in keeping with his poetic descriptions of MoS as a 'contested site, alive, resonating with ghosts 
and demons, hopes and dreams ${ }^{\prime}{ }^{57}$ Clearly the sculpture is integral in framing the experience of the visitor, and particularly in positioning MoS as a museum concerned with 'place' rather than 'beginnings'. Indeed, Edge of the Trees is a preview of what the visitor can expect to see inside the Museum. As architectural critic Andrew Nimmo observed, in this sculpture 'myth and history are combined in a way that fuses the past tragedies of the Eora peoples, the discarded from England and the land stripped bare, so that the year 1788 might be seen in its context - not merely as a beginning, but as a significant event in a continuous history' ${ }^{58}$ The same message is repeated throughout MoS as the visitor is urged to understand 1788 as a 'turning point' for two cultures rather than as the birth of a nation.

Upon entering MoS, visitors are exposed to The Calling to Come - an auditory exhibition based on the diaries of First Fleet officer Lieutenant William Dawes in which he recorded his efforts at communication with an Indigenous woman with whom he was romantically involved. The exhibition, curated by Paul Carter, is a recreation of Dawes' and Patyegarang's attempts to understand each other's culture through language and can be 'imagined as a dialogue' between the two - a 'speaking pantomime of what they might have said' ${ }^{59}$ As Witcomb notes, the exhibition is difficult to understand, but that, in and of itself, can be construed as representative of the complexities of cross-cultural encounters. ${ }^{60}$ Here, and throughout MoS, the method of display forms part of the exhibition itself.

MoS used innovative audio-visual technology to give visitors a sense of the pluralistic nature of historical interpretation. Whereas technology had been used in other museums to transform static displays into interactive exhibitions, at MoS it was used to convey the fragmentary nature of historical narratives. One example of this was in the Bond Store Tales, curated by Ross Gibson. Here visitors encountered fictional 'witnesses' - played by actors - who were intended to be representative of characters from both colonial history and contemporary society. The exhibition space held various objects that had passed through Sydney during the period 1788-1850. As visitors examined a relic, their proximity to the objects triggered a holographic image that would then tell its story. Gibson refers to the images as 'ghosts', explaining that once they have been 'conjured by curiosity, these phantoms are compelled to tell about the object'. ${ }^{61}$ From the colonial period the images included an Indigenous woman, a trader, a marine, an Irish maid, a tavern singer, and a French woman, while the contemporary characters ranged from an archaeologist to an Indigenous 
lawyer. ${ }^{62}$ All were imaginary figures but were based on historical research. The images of these 'witnesses' - which were activated by the movement of visitors around the exhibition space - were projected onto sheets of glass, creating a holographic effect. The characters gossiped, told anecdotes, interpreted events and debated each other across time, constantly undermining received notions of the past, or in Witcomb's words 'returning to haunt modern understandings' ${ }^{63}$ Visitors were supposed to understand from this display that many issues of concern in colonial Sydney continue to be relevant, in particular nationalism, native title, land ownership and republicanism. ${ }^{64}$

On level two of the Museum is Collectors' Chests, an exhibition of cabinets created by artist Narelle Jubelin, but in fact conceived by Peter Emmett. Indeed, the artist's name is absent from the display altogether, along with any other explanatory labelling (as was characteristic of MoS). Jubelin's Collectors' Chests are stainless steel cabinets with glassfronted drawers, each individually lit with small globes that reveal a collection of objects, texts and images while the draw is held open. The drawers contain not only historical relics but also contemporary, sometimes obscure, pieces, such as the artist's swimming costume alongside accounts of shark attacks, fragments of photographs and newspapers, diaries, letters, invoices, inventories, grass mats, bone needles, shards of bone china, remnants of ladies' bonnets, whale teeth, cigars, silver spoons and Indigenous eating implements. ${ }^{65}$ Each drawer is arranged according to the 'collage principle', wherein history becomes 'aesthetic source material'. ${ }^{66}$

Collectors' Chests would be best described as an art installation, not an historical display. It alludes to historical happenings rather than providing any explanation of them. A prime example of this is the drawer entitled 'Seven Small Sketches and Four Open Frames'. This drawer was intended to address the gaps left in artist Charles-Alexandre Lesueur's sketchbook Scenes From Aboriginal Life. Next to his last unfilled frame appears the statement 'removal of children in a cloud of dust' with the only object in the drawer being a small empty bone frame. Such esoteric displays did not faze Emmett. He never intended Collectors' Chests to 'inform' the visitor in the way that most museum exhibitions do. Rather, he wanted the visitor to imagine and wonder about the people to whom the artefacts on display belonged. ${ }^{67}$ Instead of the imparting of information, the visitor's imagination was to be stoked. But was the visitor aware they were engaging with art rather than history? 


\section{AVANT-GARDE OR INDECIPHERABLE?}

When MoS opened, it was clear that its creators held what Grace Karskens has described as a deep distrust of the written word 'as something which will only confuse, prejudice and corrupt [the] pure and direct examination of material things' ${ }^{68}$ In a MoS catalogue essay, curator Paul Carter drew a distinction between captions, which he called neutralising agents of the power of objects, and quotations, which he saw as agents of imaginative liberation..$^{69}$ Carter's view echoed the sentiments of Emmett, who posited that orthodox interpretative techniques incorporating tour guides and label texts were overly didactic and imposed a 'master narrative' on the past. ${ }^{70}$ His curatorial style was predicated on the belief that language itself was a barrier to 'truth'. ${ }^{71}$ Thus the Museum had no text panels clearly explaining the site's history or why it had been preserved. Instead, visitors encountered tracts of quotations from primary sources and voice-overs from actors imparting fictional accounts relating to the 'idea' of Sydney. Ambiguity reigned at MoS. Archival sources and fictional representations were given equal standing in the Museum, and the visitor had no way of knowing whether the stories they were seeing were 'based on texts from Sydney's colonial past, or the musings of a late-twentieth-century audio-visual producer' ${ }^{72}$ Visitors conditioned by more traditional museums would perhaps view the displays as authoritative accounts rather than as fictional or artistic 'responses to the past'. But this was of little concern to the Museum as Emmett and his team had no interest in providing a factual account of history, seeking instead to impart an emotive experience.

Curiously, the absence of meaningful interpretation at MoS stands in direct contrast to its stated aims in the Museum Plan September '93, where it was noted that:

As a modern museum [MoS] must be a museum of interpretation of historical issues and contexts using all manner of evidence. Interpretation is the primary basis, the modus operandi for the Museum, not a secondary role to collection and conservation. ${ }^{73}$

Such an explicit edict, that interpretation would be paramount in the new Museum, seems contradictory in a situation where exhibitions were almost completely lacking in contextual analysis. Rather than allowing for multiple interpretations of history, this approach merely achieved a confused visitor experience. As National Museum of Australia curator, Guy Hansen, commented shortly after MoS opened, 
the rejection of the use of didactic text and the deliberate use of ambiguity in the presentation of artefacts did not open up new possibilities of meaning, but rather left me frustrated at not knowing what I was looking at. ${ }^{74}$

While it is true that words can be an ineffective substitute for what 'the eye falls upon and grasps in an instant', it is also the case that 'enlightenment springs from the engagement of objects with narrative, and thus with connections and evaluation' ${ }^{75}$ By refusing to narrate, evaluate and communicate, MoS could not achieve its goal of overturning the oppressive narratives of race, class, empire and nation. All the visitor was left with were historical fragments - 'a plethora of beautiful, curious, unexplained objects, jumbled flotsam and jetsam from an unexplainable past ${ }^{76}$ - rather than an alternative story to the official accounts they were already familiar with. In this way MoS represented a 'triumph of aesthetics over content'. ${ }^{77}$

Hansen's concern over the unbalanced weighting given to 'aesthetics' over 'content' harks back to the debate within museological circles of the primacy of 'objects' versus 'ideas'. Witcomb explains that the objects on display at MoS are not contextualised according to their history of use, so that although MoS is presented as a social history museum its objects are actually treated as art. ${ }^{78}$ As we have seen, many of MoS' exhibitions were really art installations, having been produced, in several instances, by artists rather than curators. ${ }^{79}$ As Rogers notes, at MoS 'archaeological artefacts have been recontextualised as high art objects and museum displays re-presented as art installation' ${ }^{80}$ Thus displays such as Collectors' Chests and Bond Store Tales, while enchanting, were often impossible for the visitor to decipher. Unfortunately, such oblique ambiguity characterised the whole of the Museum's early exhibition approach, with even Watts forced to acknowledge that: 'some of those things, they were beautifully presented, they were highly artistic, they were stunning looking things, but as a method of communication they weren't brilliant' ${ }^{81}$ This needed to be changed because, as Jane Lydon remarks, artefacts cannot 'speak' for themselves: without proper contextualisation, they are 'lumpen and stolid', sitting 'mutely like toads' ${ }^{82}$ Words, either written or spoken, are necessary to convey the object's meaning.

Consequently, for many MoS' early approach rendered it an elitist institution, with its 'demand for high levels of knowledge on the part of the visitor - both about history and about knowledge production in museums' ${ }^{83}$ Indeed, in the years immediately following the Museum's opening, social historians were highly critical of the lack of textual 
interpretation, arguing that 'perhaps there is an ironic outcome in this Museum; that is, that its democratic and libertarian urges speak only to those with enough cultural capital to make the link between abstract philosophy and what they see and engage with in the Museum ${ }^{\prime}{ }^{84}$ In its attempts to highlight the multiplicity of historical experiences, Emmett had created a museum where it was almost impossible to ascertain any declaration of cause and effect such as one would expect from an authoritative institution like the museum..$^{85}$ Thus MoS became 'a museum for museum lovers and for those with an interest in contemporary media installations' rather than a museum for the general public. ${ }^{86}$ Historians such as Peter Spearritt continued to level criticism at MoS a decade after its opening, observing that it 'caters for an educated elite and has modest visitation' ${ }^{87}$ The Museum responded to such criticisms by stubbornly arguing they were 'a reaction to the potential de-frocking of the historical professionals in museums ${ }^{\prime}{ }^{88}$

Indeed, Emmett completely approved of the controversy surrounding MoS at its opening:

The very fact that the museum is controversial is a mark of its success. It is intended not only as a celebration of the architecture and the house but also as a forum for discussion and debate. ${ }^{89}$

However, while much of the controversy generated by MoS concerned its non-traditional interpretations of Australian history, there was also a great deal of concern that the displays themselves were too esoteric and therefore inaccessible to the majority of the community. Although Watts acknowledged that aspects of MoS didn't work because visitors couldn't understand what they were seeing, he also resisted suggestions it should be simplified, commenting that MoS had been pitched 'at a high intellectual level' and it didn't 'have to be for everyone'. Furthermore, he argued,

If you want to go and play with games and fiddle around on computer screens go to the Powerhouse Museum. We don't have to do it. If you want to go and have kids playgrounds and stuff, go to the National Maritime Museum or the Australian Museum. We don't have any need to do it. As a niche museum organisation that has these niche places, I've always felt that quite strongly. It is why each of our museums have very different markets... If people want to criticise 
us for not having every place accessible to every different group, let them. ${ }^{90}$

Watts' comments speak to the heart of the museum's need to identify their audiences and craft their exhibitions accordingly. Perhaps a museum can aim itself at 'cultural elites', but can a public museum do that? A museum that is funded by public money would be wise to consider whether it was accessible to as large a cross section of the public as possible. Although Watts did not want MoS to 'pitch itself down', ${ }^{91}$ he knew that the Museum's poor visitation necessitated an adjustment to its approach. As he noted:

There was no point having a few thousand people saying, "We think it is the most wonderful thing in the world". We are a public institution; we have to be appealing to a much broader group of people than that. ${ }^{92}$

MoS' adjustments, foreseen by Watts when he held back a large part of the development budget, began with a series of internal reviews.

\section{INTERNAL REVIEWS}

The Museum conducted its first internal review eighteen months after it opened. Released in November 1996, the Museum of Sydney Review focussed mostly on the public role of the Museum and less on its internal workings. It was conducted by Watts with contributions from staff and Trustees. Unsurprisingly, the Review found that although the fundamental themes of the Museum were appropriate, MoS had not achieved its potential and it was imperative that it improved its visitation numbers. ${ }^{93}$

In his Review submission, Emmett confirmed the relevance of the 1993 Museum Plan as accurately reflecting the aims and character of MoS since its opening. He commented on the opposing views of visitors wherein one half were supportive of the Museum's unconventional approach to Sydney, while the other half wanted a traditional, chronological narrative of the city's history since 1788, ultimately arguing that these views could not be reconciled, and therefore the Museum had to decide which approach it wanted to take. However, Watts - and the Trust - disagreed with Emmett's assessment. Watts instead argued for the incorporation of both approaches, for the pragmatic reason that the Trust could ill afford to alienate a substantial sector of the community by failing to respond to their needs given the paucity of MoS' visitor numbers, which in 1995-1996 was 73,247 - half of 
what had been projected for that period. Many people who visited MoS - including then NSW Premier Bob Carr - wanted a narrative that would give the Museum's fragmentary displays some form of coherence. ${ }^{94}$ Thus it was recommended that a broad chronological framework of the history of Sydney be integrated into the Museum, along with additional interpretation including film, labels, audio guides, pamphlets and guidebooks.

Given Watts' decision to hold back some of the development budget, the Trust had available funding to address the public criticisms, but Watts had trouble getting traction with staff to implement changes. Several members of staff resented the suggestion that what they were doing needed adjustment and little progress was made towards achieving the recommended curatorial changes. ${ }^{95} \mathrm{In}$ fact, it was not until 1999 - three years after the initial recommendation - that the Museum added new panels of contextual information adjacent to each major display and a light box display on level three that provided a broad chronological framework. ${ }^{96}$ Watts has explained that the delay was due to personnel issues. The team of people assembled by Emmett had invested inordinate amounts of time, energy and creativity in MoS' exhibitions and were unable to accept the Review's criticism of their work. ${ }^{97}$ Emmett, as their leader, supported their work and was similarly opposed to the proposed changes. In his address to the internal forum held to discuss the Review, Emmett argued against any alteration to the 'spatial readings of Sydney' that would introduce a chronological perspective. The Trustees disagreed, observing that Emmett had set up a 'false dichotomy' that suggested the Museum's interpretative approach could only be either chronological or spatial but not both. ${ }^{98}$

In the end, significant personnel changes were required in order to implement the Review's recommendations. In Watts' words, the team had been 'holding on to a vision, which had been incredibly exciting, but at the end of the day, for many people, didn't work'. ${ }^{99}$ Although Emmett and his team couldn't accept the public's negative response to MoS, as a public institution MoS had to appeal to a broader audience and needed to respond to the public's criticisms. Following a further review of the Museum in 1998, the position of Senior Curator MoS - Emmett's position - was replaced with Senior Curator in the new Major Projects Unit. This involved working on several nominated projects - essentially temporary exhibitions - rather than being responsible for curation at MoS as a whole. ${ }^{100}$ By the time of the March 2000 review the Trust had decided on a new management structure for MoS to assist it in achieving its longterm goals, specifically an increase in visitation. ${ }^{101}$ Emmett left the 
Museum shortly thereafter, either unaware or unwilling to accept that MoS was always intended to evolve following his 'first putt'. ${ }^{102}$

Watts has lamented the slow implementation of the 1996 Review's recommendations. ${ }^{103} \mathrm{He}$ admits that the Museum lost a lot of public support in its early years of operation as a result of not having moved quickly enough to address the public's concerns with its curatorial style. Only once personnel changes were made was MoS able to improve its accessibility through increased interpretative text panels and the introduction of summaries incorporating a chronological framework that helped to further explain the Museum, and Sydney, to visitors. As Watts had suspected, MoS needed to develop from its 'first putt' into a more accessible, and thus viable, public institution.

\section{CONCLUSION}

From the outset, MoS has engaged with historiographical developments that challenged the notion of a singular, linear narrative of the past and that sought more inclusive interpretations of history. This approach was always going to be controversial, but as a public institution, the Trust needed it to also be viable. Yet by privileging the aesthetic over meaningful interpretation, MoS not only rejected metanarratives, it also alienated visitors who were unable to grasp its mission.

In the end, MoS' beautiful and provocative displays failed to communicate Emmett's laudable message because they were incomprehensible to much of its audience. While Emmett and his team refused to entertain any suggestion that their vision was not appropriate, the pragmatism of Watts and the Trust ultimately won out and the displays that did not work were changed to ones that did. Watts knew from the beginning that incorporating new academic styles in any museum was risky. He was acutely aware that MoS' approach might need to be adjusted in due course, setting aside money for this very purpose. But Emmett could not compromise his vision.

$\mathrm{MoS}^{\prime}$ early attempts to incorporate historiographical developments into its displays may lend credulity to Dean and Rider's assertions that public museums are not the right place for the exploration of complex concepts. ${ }^{104}$ However, the criticisms MoS encountered centred on its role in communicating the past to its audiences. Simply, without narrative and interpretation, a museum's message remains inaccessible, meaning it hasn't fulfilled its responsibility to the publics it serves. 


\section{ENDNOTES}

${ }^{1}$ Paula Hamilton and Paul Ashton, 'At Home with the Past: Background and Initial Findings from the National Survey', Australian Cultural History, no 23, 2003, pp5-30, at pp14 and 17.

${ }^{2}$ Carol Duncan, Civilizing Rituals: Inside Public Art Museums, Routledge, London, 1995, p6.

${ }^{3}$ Ludmilla Jordanova, History in Practice, Hodder Arnold, London, 2006, p129.

${ }^{4}$ Sharon Macdonald, 'Expanding Museum Studies: An Introduction', in Sharon Macdonald (ed), A Companion to Museum Studies, Blackwell Publishing, Malden, MA, 2006, pp1-12, at p3.

${ }^{5}$ See Peter Vergo (ed), The New Museology, Reaktion Books, London, 1989.

${ }^{6}$ See, for example, Dawn Casey, 'The National Museum of Australia: Exploring the Past, Illuminating the Present and Imagining the Future', in Darryl McIntyre and Kirsten Wehner (eds), National Museums: Negotiating Histories, National Museum of Australia, Canberra, 2001, pp3-11, at p3.

${ }^{7}$ Peter Emmett, 'WYSIWYG on the Site of First Government House', Sites - Nailing the Debate: Archaeology and Interpretation in Museums Seminar 7-9 April 1995, Historic Houses Trust of New South Wales, Sydney, 1996, pp107-120, at p107.

${ }^{8}$ Dawn Casey, 'Museums as Agents for Social and Political Change', Curator, vol 44, no 3, 2001, pp230-236, at p230.

${ }^{9}$ Darryl McIntyre, 'Creating New Pasts in Museums: Planning the Museum of London's Modern London Galleries', in Paul Ashton and Hilda Kean (eds), People and Their Pasts: Public History Today, Palgrave Macmillan, Basingstoke, 2009, pp131145, at pp138-139

${ }^{10}$ David Dean and Peter E. Rider, 'Museums, Nation and Political History in the Australian National Museum and the Canadian Museum of Civilization', Museum and Society, vol 3, no 1, 2005, pp35-50, at p44.

${ }^{11}$ Department of Planning, First Government House Site, Sydney, p1.

${ }^{12}$ ibid, p6.

${ }^{13}$ Joy Hughes (ed), First Government House Site in the 20th Century, Historic Houses

Trust of New South Wales, Sydney, 1995, p9.

${ }^{14}$ Stephen Alomes, A Nation at Last? The Changing Character of Australian Nationalism 1880-1988, Angus \& Robertson Publishers, North Ryde, 1988, p170.

${ }^{15}$ The Sydney History Group, founded by Max Kelly, Jill Roe and Peter Spearritt, was a Macquarie University-based group that published the journal, Sydney Gazette, from 1978 to 1986, and co-published several academic texts on urban history. See Paul Ashton, 'Duncan Waterson: Public Historian', Journal of Australian Studies, vol 25, no 69, 2001, pp17-22, at p20.

${ }^{16}$ Author Interview with Peter Watts, on 5 February 2007.

${ }^{17}$ Peter Watts, First Government House Site - a Report Attached to the Agenda for a Historic Houses Trust Meeting Held on 17 October 1988, Historic Houses Trust of New South Wales, Sydney, 1988.

${ }^{18}$ Hughes (ed), First Government House Site in the 20th Century, p16.

${ }^{19}$ Author Interview with Peter Watts.

${ }^{20}$ ibid.

${ }^{21}$ ibid.

${ }^{22}$ ibid.

${ }^{23}$ Andrea Witcomb, Re-Imagining the Museum: Beyond the Mausoleum, Routledge, London, 2003, p155.

${ }^{24}$ Margaret Anderson, 'Selling the Past: History in Museums in the 1990s [Paper in Special Issue: Packaging the Past? Public Histories, Edited by John Rickard and Peter Spearritt]', Australian Historical Studies, vol 24, no 96, 1991, pp130-141, at p133.

${ }^{25}$ Author Interview with Peter Watts. 
${ }^{26}$ Kate Gregory, 'Art and Artifice: Peter Emmett's Curatorial Practice in the Hyde Park Barracks and Museum of Sydney', Fabrications, vol 16, no 1, 2006, pp1-22, at p1.

${ }^{27}$ Ann Curthoys, 'The Museum and New Ways of Understanding Australian History', Sites - Nailing the Debate: Archaeology and Interpretation in Museums Seminar 7-9 April 1995, Historic Houses Trust of New South Wales, Sydney, 1996, pp217223, at p221.

${ }^{28}$ Sue Hunt, 'The Museum of Sydney on the Site of First Government House: A Controversial Museum on a Contested Site', paper presented to International Scientific-Practical Conference: History Museums as Part of Town Culture, Moscow, 1996, pp4-5.

${ }^{29}$ Jean-François Lyotard, The Postmodern Condition: A Report on Knowledge, University of Minnesota Press, Minneapolis, 1984, pxxiv.

${ }^{30}$ Willie Thompson, Postmodernism and History, Palgrave Macmillan, Houndmills, Basingstoke, Hampshire, 2004, p15.

${ }^{31}$ Peta Landman, 'The Museum of Issues', The Sydney Review, December, 1994, pp4-5, at p5.

${ }^{32}$ ibid, p4.

${ }^{33}$ Emmett, 'WYSIWYG on the Site of First Government House', p116.

${ }^{34}$ ibid, p115.

${ }^{35}$ ibid, pp115-116.

${ }^{36}$ ibid, pp118-120.

${ }^{37}$ Naomi Stead, 'The Housing of History: The Museum of Sydney as Contemporary "Cabinets of Curiosity"', in Andrew Leach and Emina Petrovic (eds), Formulation Fabrication: The Architecture of History - Proceedings of the Seventeenth Annual Conference of the Society of Architectural Historians, Australia and New Zealand, The Society of Architectural Historians, Australia and New Zealand, Wellington, New Zealand, November, 2000, pp85-92, at p91.

${ }^{38}$ Rebecca Haagsma, Guwanyi: Stories of the Aboriginal Community, Historic Houses Trust of New South Wales, Sydney, 1996.

${ }^{39}$ Stead, 'The Housing of History: The Museum of Sydney as Contemporary "Cabinets of Curiosity"', p89.

${ }^{40}$ Linda Young, 'Museum of Sydney', Museum National, August, 1995, pp24-26, at p25.

${ }^{41}$ Paul Carter, The Road to Botany Bay: A Spatial History, Faber, London, 1987.

${ }^{42}$ Historic Houses Trust of New South Wales, Museum Plan September '93, Historic Houses Trust of New South Wales, Sydney, 1993, p21.

${ }^{43}$ Peter Emmett, Edge of the Trees Concept Brief, Historic Houses Trust of New South Wales, Sydney, 1993, p7.

${ }^{44}$ Peter Emmett, 'Contested Ground - Contested Histories - Contested Futures', in Amareswar Galla, Bernice Murphy, and Don McMichael (eds), Museums and Cross Cultural Understanding: Papers from the 5th Regional Assembly of the Asia Pacific Organisation of the International Council of Museums 24-27 September 1993, Australian National Committee of ICOM, 1995, pp72-76, at p73.

${ }^{45}$ Landman, 'The Museum of Issues', p5.

${ }^{46}$ ibid.

${ }^{47}$ Andrew Nimmo, 'Art in a Public Place', in Dinah Dysart (ed), Edge of the Trees: A Sculptural Installation by Janet Laurence and Fiona Foley from the Concept by Peter Emmett, Historic Houses Trust of New South Wales, Sydney, 2000, pp8-11, at pp8-9.

${ }^{48}$ Rhys Jones, 'Ordering the Landscape', in Ian Donaldson and Tamsin Donaldson (eds), Seeing the First Australians, Allen \& Unwin, Sydney, 1985, pp181-209, at p185.

${ }^{49}$ Peter Emmett, 'What Is This Place?', in Dinah Dysart (ed), Edge of the Trees: A Sculptural Installation by Janet Laurence and Fiona Foley from the Concept by Peter Emmett, Historic Houses Trust of New South Wales, Sydney, 2000, pp22-23, at p23.

${ }^{50}$ Emmett, 'WYSIWYG on the Site of First Government House', p111.

${ }^{51}$ Landman, 'The Museum of Issues', p5.

${ }^{52}$ Nimmo, 'Art in a Public Place', p9. 
${ }^{53}$ Linda Burney, 'The Story of Sydney', in Dinah Dysart (ed), Edge of the Trees: A Sculptural Installation by Janet Laurence and Fiona Foley from the Concept by Peter Emmett, Historic Houses Trust of New South Wales, Sydney, 2000, pp12-13, at p12.

${ }^{54}$ 'Research and Experimentation', in Dinah Dysart (ed), Edge of the Trees: A Sculptural Installation by Janet Laurence and Fiona Foley from the Concept by Peter Emmett,

Historic Houses Trust of New South Wales, Sydney, 2000, pp52-53, at p53.

55 'Construction', in Dinah Dysart (ed), Edge of the Trees: A Sculptural Installation by Janet Laurence and Fiona Foley from the Concept by Peter Emmett, Historic Houses Trust of New South Wales, Sydney, 2000, pp64-65, at p65.

${ }^{56}$ Emmett, 'Last Words from the Protagonists', at p96.

${ }^{57}$ Emmett, 'WYSIWYG on the Site of First Government House', p111.

${ }^{58}$ Nimmo, 'Art in a Public Place', p11.

${ }^{59}$ Paul Carter, The Calling to Come, Historic Houses Trust of NSW, Sydney, 1996, p5.

${ }^{60}$ Witcomb, Re-Imagining the Museum: Beyond the Mausoleum, 160.

${ }^{61}$ Ross Gibson, The Bond Store Tales, Historic Houses Trust of New South Wales, Glebe, 1996, p4.

${ }^{62}$ Landman, 'The Museum of Issues', p5.

${ }^{63}$ Witcomb, Re-Imagining the Museum: Beyond the Mausoleum, p162.

${ }^{64}$ Jon Conomos, 'A Complex Approach to Story-Telling', Art Monthly Australia, May, 1995, pp18-19, at p18.

${ }^{65}$ Kay Schaffer, 'Reconstructing "Our" Past: The Museum of Sydney', The Olive Pink Society Bulletin, vol 8, no 2, 1996, pp22-25, at p25.

${ }^{66}$ Stead, 'The Housing of History: The Museum of Sydney as Contemporary "Cabinets of Curiosity"', p90.

${ }^{67}$ Jo Darbyshire, Restlessness of Meaning: An Exploration of How Visual Artists Are Working with Museum Collections, Master of Creative Arts (Cultural Heritage Studies) Thesis, Curtin University of Technology, 2003, p34.

${ }^{68}$ Grace Karskens, 'Engaging Artefacts: Urban Archaeology, Museums and the Origins of Sydney', Tasmanian Historical Studies, vol 7, no 1, 2000, pp39-64, at p50.

${ }^{69}$ Cited in Young, 'Museum of Sydney', p25.

${ }^{70}$ Guy Hansen, 'Fear of the "Master Narrative": Reflections on Site Interpretation at the Museum of Sydney', Museum National, November, 1996, pp18-19, at p18.

${ }^{71}$ Linda Young, 'Exhibition Review', Australian Historical Studies, vol 26, no 105, 1995, pp666-667, at p667.

${ }^{72}$ Hansen, 'Fear of the "Master Narrative": Reflections on Site Interpretation at the Museum of Sydney', p19.

${ }^{73}$ Historic Houses Trust of New South Wales, Museum Plan September '93, p19.

${ }^{74}$ Hansen, 'Fear of the "Master Narrative": Reflections on Site Interpretation at the Museum of Sydney', p19.

${ }^{75}$ Karskens, 'Engaging Artefacts: Urban Archaeology, Museums and the Origins of Sydney', pp54-55.

${ }^{76}$ Ibid., p55.

${ }^{77}$ Hansen, 'Fear of the "Master Narrative": Reflections on Site Interpretation at the Museum of Sydney', p19.

${ }^{78}$ Witcomb, Re-Imagining the Museum: Beyond the Mausoleum, p163.

${ }^{79}$ Ibid.

${ }^{80}$ Catherine Rogers, 'Terra Nullius and the Museum of Sydney', The Olive Pink Society Bulletin, vol 8, no 2, 1996, pp9-21, at p17.

${ }^{81}$ Author Interview with Peter Watts.

82 Jane Lydon, 'Many Inventions': The Chinese in the Rocks, Sydney, 1890-1930, Department of History, Monash University, Clayton, Victoria, 1999, p176.

${ }^{83}$ Witcomb, Re-Imagining the Museum: Beyond the Mausoleum, p163.

${ }^{84}$ Maryanne McCubbin, 'Contemporary Culture and Curators', Insite, September, 1995, pp3-4, at p3.

${ }^{85}$ Young, 'Exhibition Review', p666.

${ }^{86}$ Witcomb, Re-Imagining the Museum: Beyond the Mausoleum, p163. 
${ }^{87}$ Peter Spearritt, 'Positioning: On Site and in Situ', in Graeme Davison and Kimberley Webber (eds), Yesterday's Tomorrows: The Powerhouse Museum and Its Precursors 1880-2005, Powerhouse Publishing in association with UNSW Press, Sydney, 2005, pp240-253, at p252.

${ }^{88}$ McCubbin, 'Contemporary Culture and Curators', p3.

${ }^{89}$ Peter Emmett, quoted in Jill Sykes, 'The New and Revealing Museum of Sydney', The View, no 1, 1995, pp48-53, at p53.

${ }^{90}$ Author Interview with Peter Watts.

${ }^{91}$ ibid.

${ }^{92}$ ibid.

${ }^{93}$ Peter Watts, Museum of Sydney Review, Historic Houses Trust of New South Wales, Sydney, 1996, p4.

${ }^{94}$ Author Interview with Peter Watts.

${ }^{95}$ Historic Houses Trust of New South Wales, Review of Staff Structure and Operations at the Museum of Sydney, Historic Houses Trust of New South Wales, Sydney, 2000, p10.

${ }_{96}$ Peter Watts and MoS Management Team, Report on the Implementation of 1997 MoS Review, Historic Houses Trust of New South Wales, Sydney, 10 April 1999.

${ }^{97}$ Author Interview with Peter Watts.

${ }^{98}$ Historic Houses Trust of New South Wales, 'Minutes of Forum to Discuss MOS Review: Trustees and MOS Staff', 4 November 1996, pp2-3.

${ }^{99}$ Author Interview with Peter Watts.

${ }^{100}$ Historic Houses Trust of New South Wales, Review of Staff Structure and Operations at the Museum of Sydney, p9.

${ }^{101}$ ibid, p10.

${ }^{102}$ Author Interview with Peter Watts.

${ }^{103}$ ibid.

${ }^{104}$ Dean and Rider, 'Museums, Nation and Political History in the Australian National Museum and the Canadian Museum of Civilization', p44. 